研究課題別評価

1 研究課題名:

強磁性金属ナノコンポジット膜を用いた Left-Handed Materials の実現と応用

2 研究者氏名:冨田 知志

3 研究のねらい:

物質の電磁気応答を決定する誘電率と透磁率が共に負となる物質は、Left-Handed Materials (LHMs) と呼ばれる。本研究では強磁性金属ナノコンポジット膜を用いて、これまで実 現不可能と言われてきた LHMs をマイクロ波領域で創製することを目的とする。本研究の成果 は、物質の電磁気応答における従来の既成概念を打ち破るブレイクスルーとなり、将来的な光 ディスクの超高密度化等に繋がる基盤技術へと発展すると期待される。

4 研究成果:

強磁性金属ナノ粒子が埋め込まれた非磁性絶縁体膜(強磁性金属ナノコンポジット膜)を用 いて、マイクロ波領域での LHMs の実現と応用を目指した研究を行った。研究の各段階での具 体的な目標は、(1)強磁性金属ナノ粒子のサイズ及び体積充填率が制御されたナノコンポジット 膜の作製、(2)ナノコンポジット膜の構造及び物性の解明、(3)マイクロ波領域での LHMs としての 機能発現の確認、(4)光の領域への展開も含めた応用展開であった。以下、順に研究成果を示 す。

(1)ナノコンポジット膜の作製を行った。まず、同時スパッタリング法により、直径数 $n m$ のFeナノ 粒子が埋め込まれた $\mathrm{SiO}_{2}$ 薄膜を作製した[論文 5]。しかし、同時スパッタリング法のような物理 的手法では、作製可能な試料の量に限界があり、またコンポジット膜の微細構造、特に粒子サ イズと充填率の独立かつ精密な制御は困難であった。よって次に、化学的手法を試みた。表面 改質法を応用し、強磁性金属であるNiのナノ粒子を有機高分子膜(ポリイミド、PI)に埋め込んだ。 作製手順は、KOH処理によるPIの表面改質、イオン交換反応を用いた改質層へのNiイオンの埋 め込み、水素ガス中での熱処理によるイオン還元に伴うNiナノ粒子形成、である。図 1 に、7 分 間 $K O H$ 処理し、 $300^{\circ} \mathrm{C} て ゙ 30$ 分間熱処理したNi-PI膜の、膜断面の透過型電子顕微鏡 (TEM) 像を 示す。一様に分散した平均粒径 $8 \mathrm{~nm}$ 程度のNiナノ粒子が確認できる。詳細なTEM観察の結果、 熱処理後に形成されるNiナノ粒子の直径は、KOH処理時間に依存することが明らかになった [論文 4]。KOH処理時間を 1 分から 15 分まで変化させると、Niナノ粒子の直径は約 $5 \mathrm{~nm}$ から 10nmまで変化した。一方、熱処理によるPIマトリックスの熱分解と収縮を用いることで、コンポジ ット層中のNi粒子の相対的な体積充填率を増加させることができた。図2にKOH処理時間 7 分 の試料での、Ni粒子の直径と体積充填率の熱処理時間依存性を示す。粒子直径は、時間に依 らず約 $8 \mathrm{~nm}$ で一定であることがわかる。一方、長時間の熱処理により、体積充填率は $3.2 \%$ か 18\%まで増加している。以上より、KOH処理時間及び熱処理時間などの作製条件を制御するこ 
とで、Ni-PI膜中のNiナノ粒子のサイズと体積充填率を独立かつ精密に制御することに成功した [特許出願済み]。なお本手法による粒子サイズと充填率の独立制御は、非磁性金属ナノ粒子 の場合でも有効であり、汎用性を有すると考えられる[論文 3]。

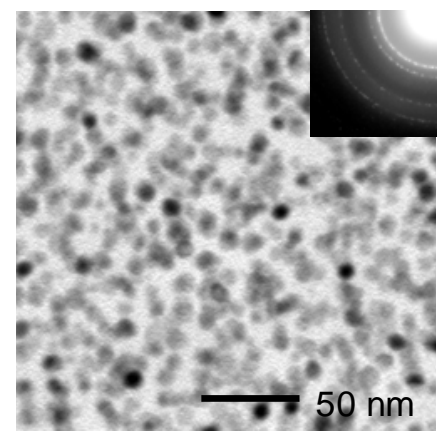

図1 Ni-PI 膜断面 TEM 像 $(\mathrm{KOH}-7$ 分間処理、 $300^{\circ} \mathrm{C} 30$ 分間熱処理)



図 2 粒子サイズと充填率の熱処理温度依存 性 ( $\mathrm{KOH}-7$ 分処理試料)

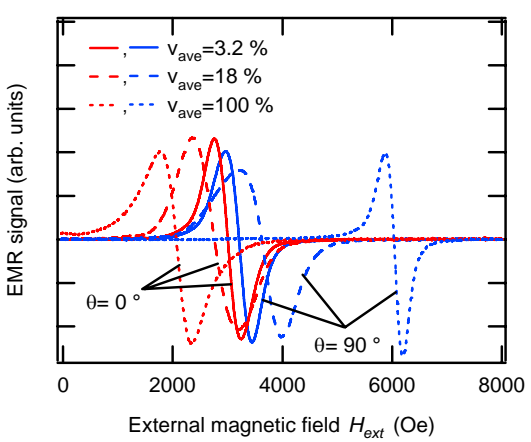

図 $3 \mathrm{Ni}-\mathrm{PI}$ 膜の $X$ バンドでの EMR 信号 $(\mathrm{KOH}-7$ 分処理試料) 波領域で負の透磁率 $(\mu)$ を得るために利用す る物理現象である。よって EMR 条件が膜の微 細構造とどのような相関関係にあるか、を明らかにしておくことは重要であった。室温での EMR 信号を図 3 に示す。図の横軸は外部磁場である。膜中の Ni 粒子の直径は約 $8 \mathrm{~nm}$ であった。体 積充填率が $3.2 \%$ の試料が示す共鳴磁場は、磁気的に孤立しているバルク Ni 球の共鳴磁場と ほぼ一致している $(g=2.21)$ 。よって充填率 3.2\%の試料では、粒子間の磁気双極子相互作用は ほぼ無視できると言える。ところが体積充填率の増加に伴い共鳴磁場が、外部磁場を膜面に対 して平行に加えた場合 $\left(\theta=0^{\circ}\right)$ は低磁場側(見かけ上の $g$ 值が大きくなる方向)に、垂直に加え た場合 $\left(\theta=90^{\circ}\right)$ は高磁場側(見かけ上の $g$ 值が小さくなる方向)にシフトしていることが判る。 この磁場シフト量は、Ni粒子間の磁気双極子相互作用の計算から得られた、一粒子が感じる双 極子磁場の増加量とほぼ一致した。よって体積充填率の増加により、Ni 粒子間の磁気双極子 
相互作用が強くなり、双極子磁場が増加しEMR の共鳴磁場がシフトすることが半定量的に説明 できた。即ち、強磁性金属ナノコンポジット膜の EMR では、粒子間の磁気双極子相互作用が重 要な役割を果たすことが明らかになった[論文 2]。

双極子相互作用を持つNiナノ粒子系でのEMRを更に詳細に調べるために、計算機実験を行 つた。計算モデルは双極子相互作用を考慮に入れた $9 \times 9 \times 5$ の 3 次元配置Niナノ粒子系であっ た。Ni粒子直径は、実験と同じ、 $8 \mathrm{~nm}$ とした。面内 $(9 \times 9)$ 方向には周期的境界条件を設定し、0 Kでのランダウ・リフシッツ・ギルバート (LLG) 方程式を解き、粒子の磁気モーメントのダイナミク スを調べた。粒子内のギルバートダンピング定数 $(\alpha)$ は 0.01 で一定とした。外部振動磁場の周

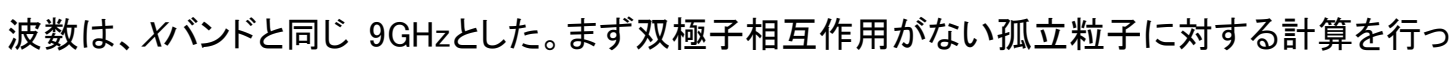
た。バルクNiのg值(2.21)から予想される $32130 \mathrm{e}$ 付近に共鳴が現れ、計算に問題がないことを 確認した。次に、双極子相互作用を入れ、粒子間距離を変化させて計算を行った。その結果、 粒子間距離の減少に伴い、測定結果と同様にEMR信号の共鳴磁場がシフトした。そのシフト量 は測定結果を定量的に良く再現した。また粒子間距離の減少に伴い、共鳴信号の強度減少が 見られた。EMR信号強度は、ピーク強度 $\times(\text { 半值幅 })^{2}$ で表される。しかし今回は信号の半地幅は 一定であった。この信号強度減少は、双極子磁場の面内成分の増加の影響と考えられる[論文 作成中]。また同じモデルで、乱数的に粒子サイズをばらつかせ、粒子サイズ分布を持ったNiナ ノ粒子系での計算機実験も行った。こちらの方が実験で使用しているNi-PIにより近い。サイズ 分布の増大に伴い、听一定にもかかわらずEMR信号の半值幅が増大した。これは双極子磁 場の面内成分及び面直成分のばらつきの増大に起因すると考えられる。このことは $0 \mathrm{kであっ}$ ても、高充填率でサイズ分布を持ったランダムな粒子系では、信号の著しいブロードニングによ りEMR信号が見かけ上消失することを予言していると考えられる[論文作成中]。このような相互 作用を持った粒子系での磁気ダイナミクスには、まだ不明な点が多く、実験·理論の両面から更 に研究を進める必要がある。

更に、目標(3ママイクロ波領域での LHMs としての機能発現の確認を目指した。磁場下での強 磁性金属ナノコンポジット膜に対して、10-100GHz 帯マイクロ波の透過・反射特性が周波数掃引 で測定可能なシステムが必要であった。よって、貫通型ボア中に6T まで励磁可能な無冷媒超 電導マグネットを導入し、ベクトルネットワークアナライザと組み合わせ、測定システムを新たに 構築した。測定システムをチェックするための標準試料として、イットリウム鉄ガーネット(YIG) 粉 末ペレットのマイクロ波透過特性を調ベた。 $90 \mathrm{GHz}$ 帯 (波長約 $3 \mathrm{~mm}$ )での周波数掃引測定の結 果、YIG の磁気共鳴によるデイツプが観測された。その後もシステムの改良を重ね、更なる高安 定化·高感度化を図った。そして、強磁性金属ナノコンポジット膜試料の測定を行った。膜厚約 $100 \mu \mathrm{m}$ の Ni-PI 膜を 57 枚重ねたものを試料として使用した。膜面に垂直に 1.6-2.8T の磁場を 印加すると、周波数掃引のマイクロ波透過スペクトルにディップが現れた(図 4)。ディップの $g$ 值 は、 2.15 とバルク Niの $g$ 值よりも小さかった。Xバンドでの実験結果を考慮すると、これは Niナ ノ粒子からの EMR 信号であると考えられる。即ち、我々は周波数掃印測定では初めて、Niナノ 粒子系からの EMR 信号の観測に成功した。しかし、ここで大半のマイクロ波は Ni-PI 膜試料を 透過していた。これは、Ni-PI 膜だけでは誘電率 $(\varepsilon)$ が正であることを示している。それゆえ、マ 

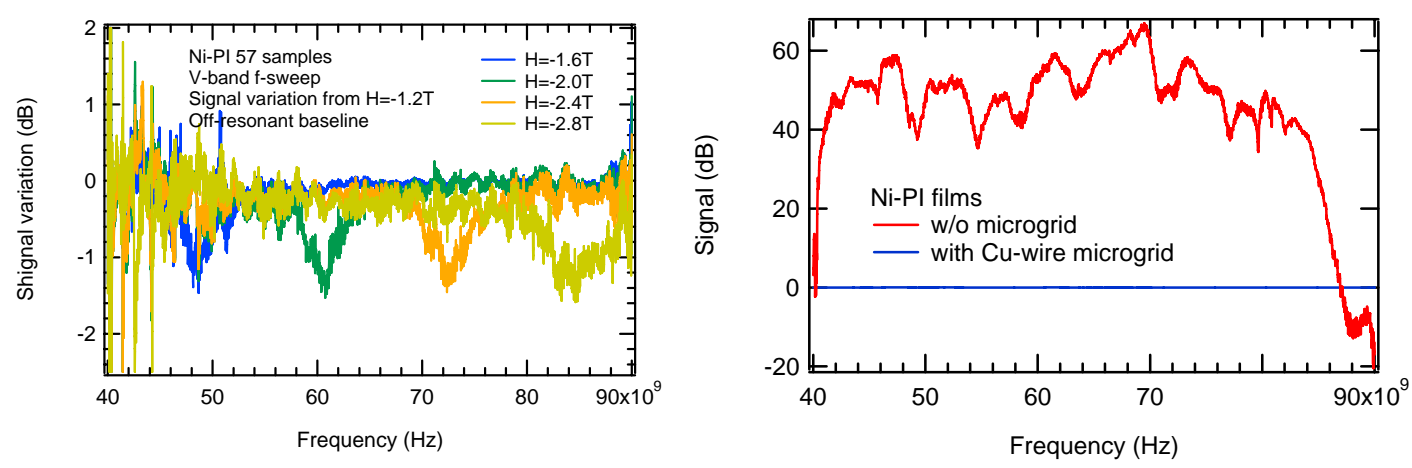

図 $5 \mathrm{Ni}-\mathrm{PI}$ 膜上に直接蒸着した $\mathrm{Cu}-\mathrm{MWG}$ の無磁場下で

図 4 磁場下の Ni-PI 膜試料のマイクロ波透過ス

のマイクロ波透過特性

ペクトルに現れた Niナノ粒子の EMR 信号

イクロメートルサイズの Cu マイクロワイヤグリッド(Cu-MWG)を試料に組み込み、それに負の $\varepsilon$


らをマイクロ波の波長 (数 $\mathrm{mm}$ ) より十分小さい周期で繰り返すことで、実効的にとと $\mu$ が同時に負 となる LHMs を実現することを目指した。マスクを用いた真空蒸着法により、ワイヤ径 $100 \mu \mathrm{m}$ で 間隔 $600 \mu \mathrm{m}$ の Cu-MWG を Ni-PI 膜上に直接作製した。計算から求められた、この構造の Cu-MWG の擬プラズマ周波数は約 $150 \mathrm{GHz}$ である。よってこの Cu-MWG を用いて、実効的に負 の๕が $90 \mathrm{GHz}$ 帯で実現できると考えられる。実際に無磁場下でマイクロ波透過率を測定すると、 マイクロ波はほとんど透過しなかった(図 5)。現在、最適化した Cu-MWG と Ni-PI 膜を組み合わ せた試料を作製し、実証実験を継続中である。

最後に、目標(4)光の領域への展開も含めた応用展開、に関連した成果を記す。物理的、エ 学的両観点から、更なる高周波、即ち赤外、近赤外、可視光など光の領域での LHMs および負 屈折率媒質 (NIMs) の実現が求められる。しかし、強磁性金属ナノ粒子での EMR を利用する限 り、光の領域に到達する可能性は極めて低い。EMRを利用したLHMs の稼動周波数の上限は、 外部磁場によって決まる。例えば、 $g=2.21$ の孤立 $\mathrm{Ni}$ ナノ粒子の場合、現在使用しているマグネ ットで最大磁場 $6 \mathrm{~T}$ を印加しても、200GHz 程度が上限である。仮に $100 \mathrm{~T}$ 程度の強力な磁場をか ければ $3 \mathrm{THz}$ まで周波数は上がるが、それでもせいぜい赤外領域であり、またそのような実験 は現状では現実的ではない。更に双極子相互作用をもつ現実のナノ粒子系の場合、膜に垂直 に磁場をかけた場合、見かけ上の $g$ 值は小さくなり、より低周波でしか共鳴しない。以上より、強 磁性金属ナノ粒子を埋め込んだ強磁性金属ナノコンボジット膜を用いて、光の領域での LHMs 及び NIMs が得られる可能性は低い。そこでこの目標の下での研究は方針転換し、貴金属ナノ 粒子が分散した磁性絶縁体膜の実現に取り組んだ。具体的には、Auナノ粒子が分散した YIG 薄膜 ( $A u-Y I G$ 薄膜)の作製を試みた。このような膜では、磁場下での YIG の磁気光学 (MO) 効 果と $\mathrm{Au}$ ナノ粒子の局在表面プラズモン(LSP) 共鳴がカップルすることで、ある偏光方向を持つ 可視光領域での円偏光に対して負の屈折率を示す可能性があると考えられる。同時スパッタリ ング法により、石英基板上にAuとYIG の混合薄膜を作製した。Auの体積充填率は、1.7-10.9\% 
であった。X 線回折測定から、 $900^{\circ}$ Cのポストアニーリングを行うと、Au と YIG が共に結晶化する ことが明らかになった。膜断面の TEM 観察では、直径約 $10 \mathrm{~nm}$ 程度の Au 粒子が確認された(図 6)。またアニーリング後の膜を SQUID 磁力計で測定した結果、ヒステリシス曲線は自発磁化を 示した。これは結晶化した YIG のフェリ磁性を反映していると考えられる。以上より、同時スパッ タリング法とポストアニーリングにより、Au-YIG 薄膜が作製できることが明らかになった。膜の紫 外·可視光透過吸収スペクトルを測定した結果、約 $600 \mathrm{~nm} に A u$ ナノ粒子の LSP 共鳴による吸 収が見られた（図 7)。また、分光エリプソメトリーで膜の屈折率の波長分散を調べた結果、 $600 \mathrm{~nm}$ 近傍にLSP に起因する明確な分散が見て取れた[論文作成中]。以上より、Au-YIG 薄膜 は、600nm 付近に LSP 共鳴を持つことが示された。この波長領域での MO 効果として、極磁気 Kerr 効果を調べた。その結果、図 7 に見られるように、Au ナノ粒子が埋め込まれることで、 $600 \mathrm{~nm}$ 付近での膜の Kerr 回転角の正負が逆転した[論文 1]。この回転角反転は、YIG の MO 効 果とAuナノ粒子の LSP とのカップリングの可能性を示唆していると考えられる。回転角反転のメ カニズムの解明、及び光領域での NIMs の実現へ向けて、現在、実験と理論の両面からの更な る研究を進めている。

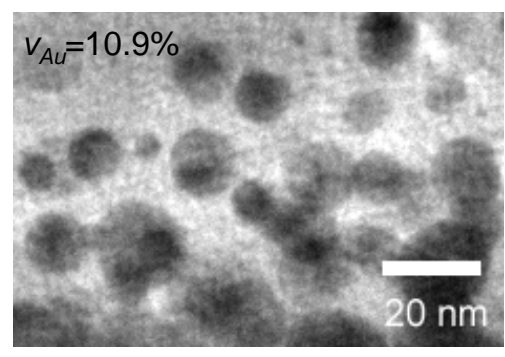

図 $6 \mathrm{Au}-\mathrm{YIG}$ 薄膜の膜断面 TEM 像



図 $7 A u-Y I G$ 薄膜の光吸収スペクトルと 極磁気 Kerr スペクトル

5 自己評価:

本研究課題では、研究の各段階で 4 つの具体的な当初目標を設定し、研究を遂行した。よつ て、得られた成果を元にそれぞれの目標の達成率を\%で示し、自己評価としたい。まず(1)強磁 性金属ナノ粒子のサイズ及び体積充填率が制御されたナノコンポジット膜の作製に関しては、 $\mathrm{Ni}-\mathrm{PI}$ 膜という新しいナノコンポジット膜を用いて 100\%達成できたと考える。次に、(2)ナノコンポ ジット膜の構造及び物性解明に関しては、Ni-PI 膜の構造と、磁気特性及び、EMR 特性との相 関を実験的に明らかにすることが出来た。また計算機実験により、測定結果を説明し、そこに潜 む物理的メカニズムの詳細を明らかにすることができた。更に実験からだけでは明らかになら なかった、新たな現象の予測もできた。よって、この目標も 100\%達成できたと考える。(3)マイク 
ロ波領域での LHMs としての機能発現の確認に関しては、無冷媒超電導マグネットを用いた新 しいマイクロ波測定システムを立ち上げた。そして、そのシステムを用いた周波数掃引測定で、 $\mathrm{Ni}$ ナノ粒子からの EMR 信号を観測できた。また Cu-MWG を作製し、そのマイクロ波透過特性を 調べた。しかし、LHMs 実現には更なる試料の改良が必要であり、現在継続して研究中である。 よって、現時点での達成率は $50 \%$ といわざるを得ない。(4)光の領域への展開も含めた応用展開 に関しては、光の領域での NIMs の実現を目指して、貴金属ナノ粒子が埋め込まれた強磁性絶 縁体薄膜 ( Au-YIG 薄膜)を作製した。その構造及び、光学特性を調べた。また、極磁気 Kerr 効 果を調べ、MO 効果とLSP 共鳴とのカップリングの存在を示唆するデータが実験的に得られると ころまでは達成できた。しかし、NIMs の実現には更なる試料の改良及び光学測定が必要であ るため、現状での達成率は $40 \%$ が潜んでいる可能性があり、今後も継続して研究していきたいと考えている。

\section{6 研究総括の見解:}

目標であった光領域における left-handed material (LHM)の実証まで至らなかったのは残念 であるが、まだポピュラーになっていない LHM の研究の中で、光の領域まで拡張しようとした時 のいろいろな課題や知見を得たことは評価できる。LHM の実現は未達としても、着実に研究を 進め、成果も着実に蓄積している点、若い研究者として高く評価できる。より解析的な研究が必 要であり、物理 (電磁光学) と物性 (磁化率と誘電率)のアプローチが必要だったが、理論面で の深まりを欠いた点が惜しまれる。

\section{7 主な論文等:}

論文 5 件

1. "Magneto-Optical Kerr Effects of Yttrium Iron Garnet Thin Films Incorporating Gold Nanoparticles",

Satoshi Tomita, Takeshi Kato, Shigeru Tsunashima, Satoshi Iwata, Minoru Fujii, Shinji Hayashi, Physical Review Letters 印刷中.

2. "Tuning magnetic interactions in ferromagnetic-metal nanoparticle systems",

Satoshi Tomita, Kensuke Akamatsu, Hiroyuki Shinkai, Shingo Ikeda, Hidemi Nawafune, Chiharu Mitsumata, Takanari Kashiwagi, Masayuki Hagiwara,

Physical Review B, Vol. 71, 180414 (Rapid Communication), May 2005.

3. "Controlling Interparticle Spacing among Metal Nanoparticles through Metal-Catalyzed Decomposition of Surrounding Polymer Matrix",

Kensuke Akamatsu, Hiroyuki Shinkai, Shingo Ikeda, Satoshi Adachi, Hidemi Nawafune, Satoshi Tomita,

Journal of American Chemical Society, Vol. 127, No. 22, pp.7980 (Communication), June 2005.

4. "A Novel Fabrication Technique for Interacting Ferromagnetic-metal Nanoparticle 
Systems: Fine-tuning of Particle Diameter and Interparticle Spacing",

Satoshi Tomita, Kensuke Akamatsu, Hiroyuki Shinkai, Shingo Ikeda, Hidemi Nawafune, Chiharu Mitsumata, Takanari Kashiwagi, Masayuki Hagiwara,

Material Research Society Symposium Proceeding, vol. 853E, pp. I5.10.1-6, January 2005.

5. "Ferromagnetic resonance study of diluted Fe nanogranular films",

Satoshi Tomita, Masayuki Hagiwara, Takanari Kashiwagi, Chusei Tsuruta, Yoshio Matsui, Minoru Fujii, Shinji Hayashi,

Journal of Applied Physics, Vol. 95, No. 12, pp. 8194, June 2004.

特許 1 件

特開 2005-139438「金属ナノ粒子コンポジット膜の製造方法」

PCT/JP2004/015458 "Production method of metal-nanoparticle composite films"

出願人: 科学技術振興機構, 発明者: 冨田知志、縄舟秀美、赤松謙祐

出願日 : 2004.10 .13

招待講演 4 件

1. "Ferromagnetic-metal nanocomposite films as a candidate for left-handed materials", （予定）

\section{Satoshi Tomita,}

International Advanced Materials Forum for Young Scientists (IAMF), February 27March 1, 2006, Mishima, Shizuoka, Japan

2. “強磁性金属ナノコンポジット膜を用いた左手系メタ物質",

冨田知志,

量子エレクトロニクス研究会「フォトンマニピュレーションとその応用」, 2006 年 1 月 12-14 日(木), 上智大軽井沢セミナーハウス

3. "Ferromagnetic-metal nanocomposite films as a candidate for left-handed materials", Satoshi Tomita,

International Workshop on Meta-materials and Negative Refraction (IWM05) Hangzhou, China, August 27-29, 2005

4. "Ferromagnetic-metal nanocomposite films: A possible candidate for left-handed materials",

Satoshi Tomita,

Nanoarchitectonics Workshop 2005 "Nano@Micro: Innovations for Nanoarchitectonics" (NAMINA 2005), March 3-4, 2005, AIST, Tsukuba 